\title{
International Environmental Evaluation for the Helical Screw Expander Generator Unit Projects in Cesano, Italy and B roadlands, New Zealand
}

\section{August 1981}

Prepared for.

U.S. Department of Energy

Division of Geothermal Energy

San Francisco Operations Office

Prepared by:

J. W. Webb

Environmental Impacts Program Environmental Sciences Division

$$
\text { and }
$$

L. J. Mezga and A.W. Reed

Geothermal Assessment Program

Environmental Impact Section

$$
\text { Energy Division }
$$

Oak Ridge National Lảboratory

Oak Ridge, Tennessee 37830

$$
\text { operated by }
$$

Union Carbide Corporation

for the

Department of Energy

Contract No. W-7405-eng-26 


\section{DISCLAIMER}

This report was prepared as an account of work sponsored by an agency of the United States Government. Neither the United States Government nor any agency Thereof, nor any of their employees, makes any warranty, express or implied, or assumes any legal liability or responsibility for the accuracy, completeness, or usefulness of any information, apparatus, product, or process disclosed, or represents that its use would not infringe privately owned rights. Reference herein to any specific commercial product, process, or service by trade name, trademark, manufacturer, or otherwise does not necessarily constitute or imply its endorsement, recommendation, or favoring by the United States Government or any agency thereof. The views and opinions of authors expressed herein do not necessarily state or reflect those of the United States Government or any agency thereof. 


\section{DISCLAIMER}

Portions of this document may be illegible in electronic image products. Images are produced from the best available original document. 
International Environmental Evaluation for the

Helical Screw Expander Generator Unit Projects in

Cesano, Italy and Broadlands, New Zealand

August 1981

Prepared for:

U.S. Department of Energy

Division of Geothermal Energy

San Francisco Operations Office

Prepared by:

J. W. Webb

Environmental Impacts Program Environmental Sciences Division

and

L. J. Mezga and A. W. Reed Geothermal Assessment Program Environmental Impact Section Energy Division

Oak Ridge National Laboratory

Oak Ridge, Tennessee 37830 operated by

Union Carbide Corporation for the

Department of Energy

Contract No. W-7405-eng-26 


\section{INTRODUCTION}

\subsection{THE IMPLEMENTING AGREEMENT}

The U.S. Department of Energy (DOE) has entered into an Implementing Agreement with the governments of Mexico, Italy, and New Zealand or their designates. The agreement provides a framework for implementing a program of cooperative research, development and demonstration of geothermal equipment between the United States and these member countries of the International Energy Agency (IEA). This program supports and is in accordance with the provisions of Article 41 of the "Agreement on an International Energy Program" (the IEP Agreement), in which the participating countries agreed to undertake national efforts in energy research and development. The program is also consistent with Chapter IV of the "Long-Term Co-operation Programme" adopted by the Governing Board of the IEA, which refers to establishment of a cooperative undertaking on geothermal energy.

The Implementing Agreement provides for the identification and initiation of various tasks, one of which is the Helical Screw Expander Generator Unit (HSE) evaluated in this report. The specific task is the testing and demonstration of a 1 MW well-head generator using the Helical Screw Expander to harness geothermal energy. Annex I to the Implementing Agreement, which describes this task, identifies DOE as operating agent and the governments of Italy, Mexico and New Zealand, or their designates, as participants. Responsibilities of the operating agent include providing the test equipment and advisors, and preparing and distributing the final report. Each participant is responsible for providing the test site, for conducting necessary site 
preparation, for installing and maintaining the equipment, and for managing the program at its site.

\subsection{HSE PROGRAM OBJECTIVES}

The objectives of the Helical Screw Expander (HSE) Generator Program are (1) to accelerate the development of geothermal resources by introducing this advanced conversion technology, (2) to provide operating experience to prospective users of the equipment, and (3) to collect data on the performance and reliability of the equipment under various geothermal resource conditions. The participants hope to achieve these goals by testing a small-scale, transportable HSE generator at existing geothermal test facilities that produce fluids of different salinity, temperature and pressure conditions.

This Environmental Evaluation has been prepared, using available information, to analyze the environmental consequences of testing the HSE generator. Its purpose is to support a decision on the need for a complete environmental review of the HSE program under the terms of Executive Order 12114, "Environmental Effects Abroad of Major Federal Actions". This Executive Order requires, review of projects which involve the release of potentially toxic effluents that are strictly regulated in the United States, or which may have significant environmental effects on the global commons, on natural or ecological resources of international significance, or on the environment of non-participating countries. The final guidelines implementing the provisions of the Executive Order for DOE have been published (DOE 1981). 
This evaluation deals with testing to be conducted at Cesano, Italy by the designated contractor of the Italian government, the Ente Nazionale per l'Energia Ellectrica (ENEL), and at Broadlands, New Zealand by the Ministry of Works and Development of New Zealand. Testing at Cerro Prieto, Mexico has already been completed by the Comision Federal de Electricidad and is not evaluated in this report. 


\section{REFERENCES FOR SECTION 1}

U.S. Department of Energy. 1981. Environmental Compliance Guide. DOE/EV-0132, U.S. Department of Energy, NEPA Affairs Division, Washington, D.C. 20585, February. 


\section{DESCRIPTION OF THE PROPOSED ACTION}

\subsection{BACKGROUND}

Present-day commercial geothermal power systems use steam turbines to convert geothermal energy into electricity. These turbines can convert only dry steam to electricity, and their performance and longevity are decreased by large amounts of moisture, particulate matter and dissolved solids. Because most geothermal resources are liquid-dominated and contain substantial quantities of impurities, a substantial amount of potential energy is often wasted. Binary-cycle systems, wherein a low bolling liquid such as butane is vaporized by the heat in geothermal water and steam, have been developed to recover some of this wasted energy, but they have proved to be expensive and cumbersome in practice (Sprankle 1973).

The Helical Screw Expander Generator Unit also converts thermal energy to electricity from both water and steam, thereby improving utilization efficiencies. In recent tests at Cerro Prieto, Mexico, the HSE efficiencies ranged from 50-66\% (Sprankle 1981). In contrast, steam turbine efficiencies are usually well below $50 \%$, when run with liquid-dominated geothermal energy (Kestin et a1. 1980). Moreover, the HSE appears to tolerate dissolved solids and particulates well. In fact, impurities in geothermal fluids may even improve HSE efficiencies by filling damaged or corroded areas, thereby reducing clearances between moving parts.

The HSE program was devised to test the performance of the HSE under a range of conditions. Testing has already been conducted at 
Roosevelt Hot Springs, U.S.A. and at Cerro Prieto, Mexico. In the following sections, the generator unit, the sites, and the test facilities are described for the testing which is planned in Italy and New Zealand. These descriptions, based only on readily available information, form the bases for the discussion of environmental consequences in Section 3.

\subsection{HSE GENERATOR UNIT}

The Helical Screw Expander consists of a pair of intermeshing helical rotors each mounted on a shaft. Gears on the shafts are such that one rotor rotates $50 \%$ faster than the other. As geothermal water and steam enter the chamber in which the rotors are encased, gradually expanding pockets formed between the rotors and the casing permit expansion of the fluid. This expansion results in a pressure drop and an increase in the mass flow of steam, which turns the output shaft connected to the rotors. Several HSE units may be operated in series and connected to a small generator. For purposes of testing, a variety of separators, cyclones and filters may be incorporated, in addition to a standard complement of measuring instruments (Sprankle 1973, 1981).

\subsection{SITE AND TEST FACILITIES AT CESANO, ITALY}

The HSE Generator Unit will be tested at the site of an existing geothermal well and test facility located near the village of Cesano, Italy. The well, Cesano \#1, is the first of five exploratory wells which have been drilled in the area, and is located about $20 \mathrm{~km}$ (12 mi) NW of Rome near the volcanic Lake Bacciano. As a result of these explorations, the geology, mineralogy and geochemistry is reasonably 
well known for the area (Baldi et al. 1975; Calami et al. 1975; Baldi et a1. 1976a, b; Funiciello et al. 1979). The region is characterized by hilly and gently sloping terrain ranging in elevation from about 200-300 $\mathrm{m}$;above sea level. The area is rural in character with a number of towns and villages no larger than several thousand inhabitants. Land use is apparently mainly agricultural, with growing of cereal, fruit and livestock predominating (Hammond 1979). The nearest population center to Cesano \#1 is the small town of Cesano, located about $3 \mathrm{~km}$ south of the well site. Another exploratory well, Cesano \#3, is located about $2 \mathrm{~km}$ from the town. All other geothermal wells are farther from towns and villages (Funiciello et al. 1979).

The Italian ENEL has constructed a test facility at Cesano \#1 in conjunction with production testing carried out in 1977-78 (ENEL 1978). The plant consists of a gas-water separator and instrumentation for measuring temperature, pressure, flow rate and brine chemistry. A lined waste disposal basin was built previously, with a capacity of about $7700 \mathrm{Mg}$ ( 8500 tons) of brine, or approximately $100 \mathrm{~h}$ of production. In conjunction with the HSE program, the Italians intend to practice minerals recovery from this basin. The remaining liquid will then be reinjected into a well which has been drilled about $3 \mathrm{~km}$ from the test well (Sprankle 1981). The exact location and characteristics of this disposal well and the status of a pipeline to the well are currently unknown.

In the initial tests of Cesano \#1, production had to be stimulated by gas injection about $105 \mathrm{~m}$ below the well head. During the testing, production would cease whenever flow rates fell below $45-55 \mathrm{Mg} / \mathrm{h}$ 
(50-60 t/h), because of steam condensation. The chemistry of Cesano brine is imprecisely known because of the difficulty in determining flow rate and phase partitioning (ENEL 1978). The best data available are listed in Table 1, which shows that dissolved solid and particulate loadings are quite high. No detectabe $\mathrm{H}_{2} \mathrm{~S}$ is produced by this well (ENEL 1978; Sprankle 1981).

\subsection{SITE AND TEST FACILITIES AT BROADLANDS, NEW ZEALAND}

The HSE Generator will be tested on an existing geothermal well (BR 22) and test facility located on North Island, New Zealand, about $30 \mathrm{~km}$ north of the Wairakei geothermal power station. The well is one of at least 32 (Risk 1975, DiPippo 1978) in the Broadlands geothermal field, which has been under investigation for about 14 years. The field covers an area of about $11 \mathrm{~km}^{2}$ on both sides of the Waikato River (Donaldson and Grant 1978). The geology of the area is reviewed in Dipippo (1978). The region is with in the mountainous interior and there are several ski slopes within $70 \mathrm{~km}$ of Wairakei (James 1980). Large commercial forests surround the geothermal fields in the region, including Broadlands. The forestry industry would be one of the major potential users of geothermal heat and electricity if development proceeds. In recent years plans have been made to construct a 75-150 MW power station at Broadlands. Final decisions on plant capacity, disposal methods, and other design options have not yet been made, but environmental analyses of the venture have been published (Bauer et al 1977; Coulter 1977; Willis 1978). Also, the environmental 
Table 1. Mean concentration of chemical constituents in 26 samples of geothermal fluids from Cesano \#1, Cesano, Italy.

\section{Chemical Constituent}

Concentration (ppm)

Total dissolved solids

363,398

Calcium

Magnes ium

Sodium

60,729

Potassium

81,178

Lithium

266

Iron

Ammonium

Rubidium

407

Cesium

Strontium

Arsenic

Chloride

27,270

Sulfate

184,444

Bicarbonate

2,678

Boric Acid

7,420

Silica

$/^{119}$

SOURCE: ENEL 1978 
impacts of the $145 \mathrm{MW}$ geothermal power plant at Wairakei, $30 \mathrm{~km}$ up the Waikato River, have been discussed (Axtmann 1975).

A test facility which was installed at BR 22 about 6 years ago will be used to test the HSE generator. Details of the facility are unknown, but it may be the modern and extensive "pilot plant" referred to by James (1980). This plant has been used mainly to test alternative methods of condensing and cooling. Plans for waste disposal are likewise unknown, but reinjection methods have been extensively studied at Broadlands (James 1980). At least one experimental reinjection well is available on the west bank of the Waikato, where BR 22 is located, and reinjection experiments have been largely successful (Willis 1978).

The chemistry of Broadlands geothermal fluids is summarized in Table 2. Where possible, values are for measurements of BR 22 fluids; otherwise, published averages for the entire field are given. 
Table 2. Concentrations of chemical constituents in geothermal fluids from Broadlands wells.

Chemical Constituent

Concentration (ppm)

Sodium ${ }^{\mathrm{a}}$

1054

Potassium ${ }^{\mathrm{a}}$

228

Chloride ${ }^{\mathrm{a}}$

1873

Sulfur Dioxide

10

Boron $^{a}$

60

Silica ${ }^{a}$

941

Bicarbonate ${ }^{b}$

175

Sulfate

27

Lithium $^{b}$

11

Arsenic ${ }^{b}$

3

Calciumb

Cesiumb

Rubidiumb

Aluminum ${ }^{b}$

Antimony ${ }^{b}$

Tungsten $b$

avalues reported for BR 22

bMean values from several other wells at Broadlands

SOURCES: DiPippo (1978)

IEA (n.d.) 
REFERENCES FOR SECTION 2

Axtmann, R. C. 1975. Environmental Impact of a geothermal power plant. Science 187:795-802.

Baldi, P., G. M. Cameli, E. Locardi, J. Mouton and F. Scandellari. 1975. Geology and geophysics of the Cesano geothermal field. U.N. Symp. on Geothermal Energy 2:871-81. May 20-29, San Francisco, California.

Baldi, P., B. Civitelli, R. Funiciello, G. Lombardi, M. Parotto and L. Serva. 1976a. Study of the stratigraphy and mineralization of the deep wells in Cesano geothermal field. Int. Congr. on Thermal Waters, Geothermal Energy and Volcanism of the Mediterranean area, Athens, Proc. Geoth. Eneray 1:71-86.

Baldi, P., R. Funiciello, E. Locardi and M. Parotto. 1976b.

Volcanologic and structural study of the Cesano goethermal area (Rome, Italy). Ibid:43-55.

Bauer, H. E., E. M. E. Jones, J. J. Stirling, D. J. Willis and P. Wu.

1977. "Environmental Impact Report for the Broadlands Geothermal Power Development," New Zealand Electricity Department, Power Development Section, Wellington, New Zealand.

Calami, A., R Cataldi, M. Dall'Aglio and G. C. Ferrara. 1977.

Preliminary report on the Cesano hot brine deposit (Northern Latium, Italy). U.N. Symp. on Geothermal Energy 1:305-13. May 20-29, San Francisco, California. 
Coulter, G. W. 1977. The ecological impact on the Waikato River of effluent from the Broadlands geothermal power station. Paper No. 26, D.S.I.R. Fresh Water Section, Ecology Division E.R.D.C., New Zealand.

DiPippo, R. 1978. Geothermal power plants of New Zealand, Philippines and Indonesia. A technical survey of existing and planned installations. U.S. Department of Energy, Division of Geothermal Energy, Report No. CATMEC/17, CO0-4051-23.

Donaldson, I. G. and M. A. Grant. 1978. An estimate of the resource potential of New Zealand geothermal fields for power generation. Geothermics 7:243-52.

ENEL. 1978. Production tests of Cesano 1 We11. Letter and attachment from C. Corvi of ENEL to Dr. M. N. Mansour of the U.S. Department of Energy, Division of Geothermal Energy, Washington, D.C. Ref. No. 1319, December 17, 1978.

Funiciello, R., G. Mariotti, M. Parotto, M. Preite-Martinez, F. Tecce, R. Toneatti and B. Turi. 1979. Geology, mineralogy and stable isotope geochemistry of the Cesano geothermal field (Sabatini Mts. volcanic system, Northern Latium, Italy). Geothermics 8:55-71. Hammond, Inc. 1979. Hammond New Contemporary World At las. Doublestay and Co., New York. 272 pp.

James, R. 1980. Geothermal investigations in New Zealand. Geothermics 9:316-9. 
Kestin, J., R. DiPippo, H. Khalifa and D. J. Ryley (eds.). 1980. Sourcebook on the production of electricity from geothermal energy. U.S. Department of Energy, Washington, D.C., August 1980, $D O E / R A / 28320-2$.

Risk, G. F. 1975. Monitoring the boundary of the Broadlands geothermal field, New Zealand. U.N. Symp. on Geothermal Energy 2:1185-9. May 20-29, San Francisco, California.

Sprankle, R. S. 1973. Electrical Power Generating System, U.S. Patent No. $3,751,673$, August $7,1973$.

Sprankle, R. S. 1981. Telephone conversation with Dr. J. W. Webb, Environmental Sciences Division, Oak Ridge National Laboratory, Oak Ridge, Tennessee, June 4, 1981.

Willis, D. J. 1978. The effect of the Broadlands geothermal power scheme on the Waikato River. Geothermal Energy Magazine 6:25-34. 
3. POTENTIAL ENVIRONMENTAL IMPACTS

\subsection{GENERAL IMPACTS}

The environmental impacts of the HSE generator test program are expected to be negligible at both sites. Because the facilities for the program are already largely in place and were installed for other purposes by the host countries, any impacts from the HSE pertain strictly to conducting of the testing program. Even considering site construction, however, impacts would be minor, because (1) only a single production well is involved and (2) additional geothermal development or exploration facilities are present at both sites. Pasqualetti (1980), in summarizing generalized land needs for geothermal development, noted that, for single wells, no more than 0.5 ha need be cleared and graded. The addition of disposal basins, test facilities and pipelines for reinjection would increase this area considerably, but the total land requirements remain small. Because, as far as can be determined, no unique ecological or cultural resources are present in either area (Sect. 2), these impacts are expected to be minor. Moreover, particularly at Broadlands where many wells have been drilled, the incremental impact of a single additional well is small.

The limited information available permits a limited analys is of specific environmental impacts of HSE operation at each site. These are discussed briefly below.

\subsection{WASTE OISPOSAL}

Provided waste disposal is by reinjection, impacts will be negligible. Only minor spills and pipeline breaks have the potential 
for surface impacts. At Cesano, concentrations of arsenic, boron (as $\mathrm{H}_{3} \mathrm{BO}_{3}$ ) and total dissolved solids (see Table 1, Section 2) exceed EPA criteria for use in crop irrigation (Kestin et al. 1980). These criteria are based on known toxicities to various crops. Surface disposal or spills, therefore, could damage vegetation in the area. In addition, concentrations of lithium may be high enough to effect some plants (Gough et al. 1979) although there is no published criterion for this element. Rubidium has also been identified as possibly hazardous (Gough et a1. 1979, Kestin et al. 1980) but the concentrations at which it may be dangerous are unknown.

At Broadlands, the fluids contain appreciable quantities of ammonia, arsenic, boron. In addition, it is possible that wastes will be disposed of to the surface, ultimately to the Waikato River. The river already receives geothermal wastes from the power plant at Wairakei. Although significant environmental impacts have been identified from these releases (Axtmann 1975), the incremental impact from an additional well (there are 60 wells discharging at Wairakei) would be minor. Willis (1978) analyzed potential impacts of fluid discharge at Broadiands and found that, for a $150 \mathrm{MW}$ power plant discharging 20 wells to the Waikato River, impacts resulting from inputs of heat and nutrients, such as ammonia and boron, would be detectable. The maximum projected temperature increase from 20 wells would be $1.7^{\circ} \mathrm{C}$ at low flow; hence, a single well would raise the temperature less than $0.1^{\circ} \mathrm{C}$ at low flow. The water classification applied to the Waikato River at Broadlands stipulates a maximum river temperature rise of no more than $3^{\circ} \mathrm{C}$ to preserve river water quality 
and ecological resources. Although this rise would stress lakes down-river (Willis 1978), the increase from a single well would not have a measurable effect. Increases in boron and ammonia resulting from discharge of a single well could have small but detectable effects on lake eutrophication; however, this effect would be temporary because of the short-term nature of the HSE testing. Increases in concentration of mercury are not expected to be detrimental to water quality or aquatic biota even for discharge of 20 wells (Willis 1978). Arsenic levels might rise unacceptably for drinking water if 20 wells were discharged but not for a single well; in any case recovery would be rapid after cessation of testing.

\subsection{HYDROGEN SULFIDE EMISSIONS}

Hydrogen sulfide $\left(\mathrm{H}_{2} \mathrm{~S}\right)$ has not been detected at Cesano and therefore is unlikely to be a problem. At Wairakei, New Zealand, $\mathrm{H}_{2} \mathrm{~S}$ emissions from all 60 wells are uncontrolled and cause a strong odor, but do not threaten human health or local biota (Pasqualetti 1980). Development activities at Broadlands probably produce some local odors, but the increment from a single well would be minor. Recently, experiments at Broadlands have included removal of $\mathrm{H}_{2} \mathrm{~S}$ (James 1980), and removal equipment may be used with the HSE.

\subsection{SUBSIDENCE}

Subsidence is unknown at - Larderello, Italy's most developed geothermal field. Unlike Larderello, however, Cesano is a liquid dominated field, and some subsidence is possible as a result of HSE testing. Because the well is not near a major waterway, even 
detectable subsidence is not likely to have serious effects such as flooding.

In contrast, Broadiands has undergone a maximum subsidence of $190 \mathrm{~mm}$ between 1968 and 1974. Withdrawals from BR 22 could produce additional detectable subsidence in an area where about $115 \mathrm{~mm}$ has already occurred (DiPippo 1978). Any effects are expected to be local and insignificant.

\subsection{BLOWOUTS}

Well blowouts can produce prolonged air and water pollution, noise, and damage to plants and animals. Because of this and the increased costs associated with blowouts, virtually all geothermal well drilling includes the use of blowout preventers (Pasqualetti 1980). Most blowouts occur during drilling but are also known from shut in, abandoned or non-productive wells. Cesano \#1 produced Italy's only blowout during drilling, but it was quickly controlled. Italy has comprehensive requirements for blowout prevention equipment (Pasqualetti 1980). In New Zealand, two blowouts have occurred at Wairakei, but apparently none at Broadlands. Thus, considering the precautions taken, and because no new wells will be drilled, there is only a small potential for blowouts at either site. The seriousness of a blowout at either site cannot be predicted because it would depend on the strength and duration of the blowout and on site specific characteristics. 